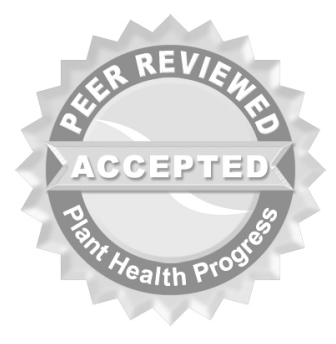

(c) 2004 Plant Management Network.

Accepted for publication 2 J anuary 2004. Published 19 J anuary 2004.

\title{
First Report of Plasmopara halstedii on Perennial Black-Eyed Susan in North Florida
}

\author{
Hank Dankers, Senior Biologist, North Florida Research and \\ Education Center; James W. Kimbrough, Mycologist, Plant \\ Pathology Department, IFAS, University of Florida, Gainesville, Florida \\ 32611-0680; M. Timur Momol, Plant Pathologist, North Florida \\ Research and Education Center, IFAS, University of Florida, Quincy, \\ Florida 32351-5677
}

Corresponding author: M. Timur Momol. tmomol@ufl.edu

Dankers, H., Kimbrough, J. W., and Momol, M. T. 2004. First report of Plasmopara halstedii on perennial black-eyed susan in North Florida. Online. Plant Health Progress doi: 10.1094/PHP-2004-0119-01-HN.

In August 2003, the Florida Extension Plant Diagnostic Clinic in Quincy, FL, received a perennial black-eyed-susan (orange coneflower) (Rudbeckia fulgida Ait. Goldsturm) plant exhibiting symptoms of downy mildew (Fig. 1). Nearly all of approximately 0.2 hectares of potted plants grown by a nursery were symptomatic. Affected plants did not produce flowers. Downy mildew has not been previously reported on perennial black-eyed-susan in Florida. This occurrence was observed after excessive rains in J uly and August 2003.

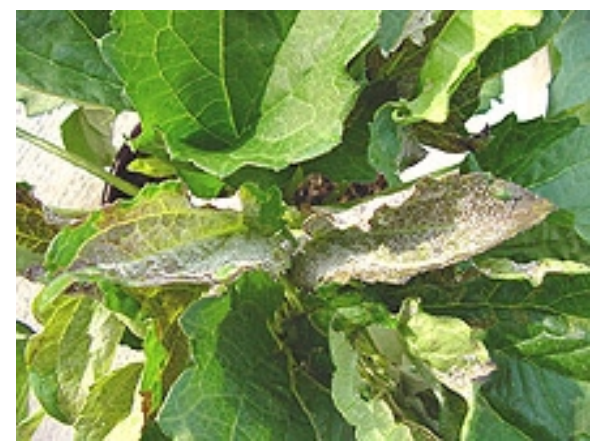

Fig. 1. Downy mildew symptoms on Goldsturm perennial black-eyed-susan leaves.

Symptoms included dark blotchy necrotic areas on adaxial leaf surface and fuzzy grayish-white areas of sporulation on both sides of affected leaves (Fig. 1). Sporangiophores were monopodially branched at right angles with acutely tapering termini (Fig. 2). Sporangia were ovoid to elliptical, hyaline (Fig. 3) and measured 21 to $27 \times 15$ to $21 \mu \mathrm{m}$. Based on these features, the organism was identified as Plasmopara halstedii (Farl.) Berl. \& de Toni (2). A voucher specimen (no. FLAS F-57538) was deposited with the Herbarium of J.W. Kimbrough at the University of Florida. Plasmopara halstedii was previously reported on Rudbeckia laciniata in northern States, on marshelder (Iva xanthifolia Nutt.) in North Dakota and on many Compositae (Asteraceae) genera $(1,2,3)$. The source of inoculum for the disease outbreak is not known. 


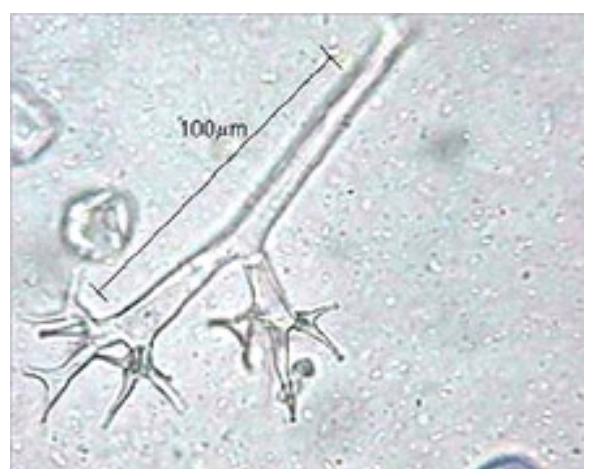

Fig. 2. Sporangiophore of Plasmopara halstedii.

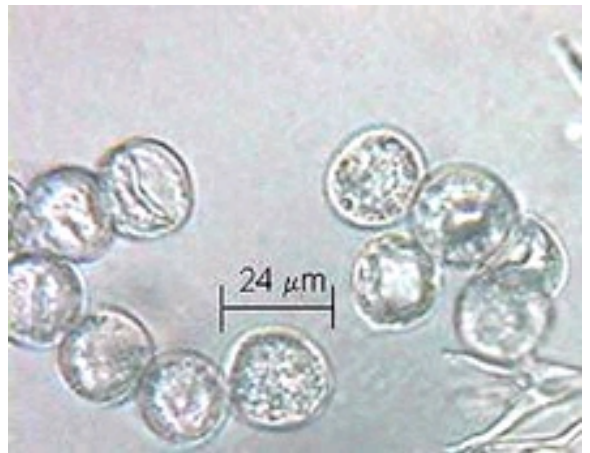

Fig. 3. Sporangia of Plasmopara halstedii.

This is the first report of $\mathrm{P}$. halstedii on perennial black-eyed-susan in Florida. This occurrence of downy mildew resulted in the loss of 6,500 potted plants that were not marketable at the targeted time frame.

Literature Cited

1. Farlow, W. G. 1883. Enumaration of the Peronosporaeae of the United States. Botanical Gazette 8:305-315.

2. Gulya, T. J. 2002. First report of cross-infectivity of Plasmopara halstedii from marshelder to sunflower. Plant Dis. 86:919.

3. Hall, G. 1989. CMI description of pathogenic fungi and bacteria no. 979. Plasmopara halstedii. Mycopathologia 106:205-207. 